tion, which must be returned before December 2 , can be obtained from the Warden, Harkness House, 38, Upper Brook Street, London, W.1, from whom further details can also be obtained.

\section{Atom School for Business Men}

NEAREY three hundred company directors and similar executives have been to four-day courses organized by the Isotope School, Atomic Energy Research Establishment, Harwell, during the past year. These courses are designed to give delegates information about current and possible future uses of radioisotopes in industry. The Isotope School at Harwell is running a further course during September 23-26 which is open to any company director or similar executive. There are still a number of places available on this course. Delegates will be housed at Worcester College, Oxford, for four nights and taken daily to Harwell. There will be lectures and demonstrations and visits arranged to atomic reactors, the Isotope Division Handling Hall and the Wantage Radiation Laboratories, where research is directed towards initiating the commercial use of large-scale irradiation sources. Further information can be obtained from the Registrar, Isotope School, Atomic Energy Research Establishment, Harwell, Didcot, Berks.

International Conference on Information Processing

AN international conference on Information Processing will be held in Paris during June 15-20, 1959. The conference is being organized by Unesco with the help of a group of consultants from various countries. Persons who wish to offer a paper should send the title, with three copies of an abstract of about 250 words, to their national group before October 1. Abstracts must be submitted in English or in French (or be accompanied by a translation in one of these languages). Further information can be obtained from the Honorary Secretary, Group $B$ Computation and Automatic Control, British Conference on Automation and Computation, c/o The Institution of Electrical Engineers, Savoy Place, London, W.C.2.

\section{University News :}

London

Dr. R. C. CurRaN, senior lecturer in the Department of Pathology of the University of Sheffield, has been appointed to the University chair of pathology tenable at St. Thomas's Hospital Medical School. Mr. M. de Burgh Daly, Locke Research Fellow of the Royal Society in the Department of Physiology at University College, has been appointed to the University chair of physiology tenable at St. Bartholomew's Hospital Medical College. Dr. P. L. Pratt, lecturer in physical metallurgy in the University of Birmingham, has been appointed to the University readership in physical metallurgy tenable at the Imperial College of Science and Technology. Dr. A. M. Cook, senior lecturer in pharmaceutics at the School of Pharmacy, has been appointed to the University readership in pharmaceutics tenable at that School.

\section{Scientific Film Association}

OwING to the continued growth in membership and the consequent increased demands on its services, the Scientific Film Association has moved to new offices in 3, Belgrave Square, S.W.1. These premises have been made available by Aslib, and it is anticipated that this closer relationship will introduce the work of the Scientific Film Association to many who are concerned with documented information of all kinds.

\section{Announcements}

Dr. Joseph AUER, head of the Department of Anatomy, Faculty of Medicine, University of Ottawa, has also been appointed assistant director of the Division of Medical Research, National Research Council of Canada, from August 1.

Prof. H. C. Darby has been appointed to fill the vacancy in the membership of the National Parks Commission created by the retirement of the Rev. H. H. Symonds.

Mr. N. S. Billington, who has been head of the National College for Heating, Ventilating, Refrigeration and Fan Engineering since February 1950, has resigned as from August 31, 1958, to take up the appointment of director of the Heating and Ventilat ing Research Council. Dr. David R. Scott, at present a senior lecturer on the staff of the Royal College of Science and Technology, Glasgow, has been appointed to succeed Mr. Billington.

THE Corday-Morgan Commonwealth Fellowship for the year 1958/59 has been awarded to Miss Rama Bhattacharya, who has, since January 1957, been junior research fellow of the Council of Scientific and Industrial Research, India, at the University College of Science, Calcutta. It will be tenable in the Department of Chemistry, University College, London, under Prof. Sir Christopher Ingold. The Fellowship is not offered for the academic year 1959/60.

A CONFERENCE on "Food and Farming : a Survey of Problems and Remedies" will be held, under the auspices of the Association of Agriculture, at the London School of Economics, on September $2 \overline{7}$. Further information can be obtained from the general secretary, The Association of Agriculture, 53 Victoria Street, London, S.W.1.

THE Scottish Group of the Nutrition Society is holding a symposium on "Nutritional Hazards caused by Radioactive Contamination of Foods" in Edinburgh on September 27. Those interested, who are not already members of the Society, are invited to write for further particulars to Dr. J. Davidson, the Rowett Research Institute, Bucksburn, Aberdeenshire.

ThE Institute of Personnel Management is to hold a conference on "The Individual and the Organization in Modern Society" at Harrogate during October 10-12. Further details can be obtained from the Institute at Management House, 80 Fetter Lane. London, E.C.4.

A MeEting of the Photoelectric Spectrometry Group will be held in Courtauld Hall, Queen Elizabeth College, Campden Hill Road, London, W.8, on October 17, at 2.30 p.m., when three papers dealing with spectropolarimetry will be read. Further information can be obtained from Mr. K. A. Mac. donald, Arbury Works, 56, Arbury Road, Cambridge.

Erratum. In the communication entitled "Reduction of Adrenochrome with Aseorbic Acid", by Dr. R. A. Heacock and Miss B. D. Laidlaw, in Nature of August 23, p. 526, there is a misprint in formula $V$ (adrenolutin); it should be

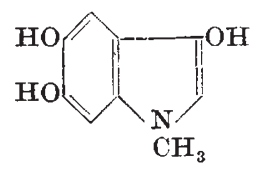

